\title{
Language Learning Strategies for Gen Z ESL Learners as Digital Natives
}

\author{
Saima Maqbool ${ }^{1, *}$, Shaik Abdul Malik Muhamed Ismail ${ }^{1}$, Saira Maqbool $^{2}$ \\ ${ }^{1}$ School of Educational Studies, Universiti Sains Malaysia, Malaysia \\ ${ }^{2}$ Allama Iqbal Open University, Pakistan
}

Received April 22, 2020; Revised June 15, 2020; Accepted July 1, 2020

Copyright $\mathrm{C} 2020$ by authors, all rights reserved. Authors agree that this article remains permanently open access under the terms of the Creative Commons Attribution License 4.0 International License

\begin{abstract}
The study aims to investigate the Gen Z ESL learners' language learning strategies as digital natives. The current study used phenomenological survey method. Quantitative data was collected through two students survey questionnaires. The first questionnaire was Oxford's language learning strategies (1990) and the second one was Timothy Teo's Digital Natives Assessment Scale (DNAS). Both the questionnaires were adapted in order to be in line with the study. Simple random sampling technique was used to collect data. A total number of 120 Gen Z Master first year students studying English language in NUST university Islamabad were selected. The data gathered revealed that Gen $\mathrm{Z}$ are more interested in using digital strategies proving that Gen $\mathrm{Z}$ truly are digital natives benefiting from learning strategies such as multitasking; using technology; graphic communication; gratifications \& rewards. But the analysis of direct and indirect strategies was also significant except for effective strategies, which was above 0.05 making the result insignificant. The study also concluded that there is not much difference in the selection of learning strategies of both the genders. Some practical implications were suggested in this regard including promotion and use of technology in language learning such as newest form of audio-visual aids. Further research to understand if these strategies correlate with learning proficiency need to be conducted.
\end{abstract}

Keywords Gen Z, Language Learning Strategies, Digital Natives, Multitasking

\section{Introduction}

English is considered as lingua franca of the $21^{\text {st }}$ century in several countries across the globe. It is the language of business, technology and communication [1]. Knowing its importance, it is also adopted as the second official language in Pakistan [2]. The reason English language learning has been one of the most discussed topics in many researches according to Rahman (1997) is this that it has been taught at all levels of education starting from primary till higher level either as a compulsory or elective subject right from the creation of the country[3]. Different aspects of language learning have been explored so forth including motivation for language learning, foreign language anxiety, language environment, language strategies and so on. Literature in the field of sociology is enriched with the topics about language in the context of four demographic groups, i.e. Baby Boomers, Generation X, Generation Y, Generation $\mathrm{Z}$ and Generation Alpha. These groups carry different traits. The classification of these groups is based on their date of birth [4], [5].

One of these groups is Gen $\mathrm{Z}$ which is the center of attention for the previous generations as they are the one currently enrolled in higher education and getting ready for entering into professional life. Realizing the significance of Gen $\mathrm{Z}$ for future becomes the responsibility of these educational institutes to provide them with relevant education according to their needs in order to make these learners more refined in language skills. Researchers and practitioners in developed countries are already working on this issue in different sub-fields of education including teaching strategies, use of technology in teaching, appropriate environment and language acquisition in accordance with the needs of Gen z [6], [7]. Nonetheless in developing county like Pakistan research on the base of specific characteristics exhibited by this generation is still lacking (i.e. excessive dependency on technology) especially in the field of English language.

The Book 'Digital Natives' was published in the beginning of $21^{\text {st }}$ century by Prensky. It explains the new generation in detail [8]. In his book, Prensky establishes and emphasizes the point that this group of learners is profoundly different from all the previous generations who 
have studied in higher education institutes. He explains this difference based on technology. He further says these learners are highly influenced by different forms of technology including mobile phones, computers, video games, podcasts, MP3 and MP4 players and many more equipment and apps for entertainment, communication and learning [8], [9]. In the light of these arguments, he claims that thinking patterns of the generation brought up in the digital world are different. He says that the reason of this different thought pattern is the presence of technology and their interaction with this technology present in abundance in the environment. He further reaches the conclusion that there is a possibility that excessive use of technology might have even changed the physical shape of human brain.

\section{Literature Review}

\subsection{Language Learning Strategies}

According to Rubin, language learning strategies include all the approaches that help a learner to develop language learning structure that can affect their learning directly or indirectly [10]. Another linguist explains language learning strategy as the particular acts that are performed by learners to make the process simple, clear, quick, entertaining, effective and can be handy or usable in different settings of learning [11]. Oxford then came up with his famous SILL (Strategy Inventory for Language Learning) to explore different learning strategies used by different learners.

\subsection{Strategy Inventory for Language Learning (SILL)}

In 1990 Oxford developed the Strategy Inventory for Language Learning (SILL) which is used in linguistic and educational researches all over the world till date as it is one of the highly validated and reliable instrument. The language learning system is grouped into two major sets that is further divided into six areas, as described in Figure 1. The first category refers to direct strategies that include memory, cognitive, and compensation strategies. The second category refers to indirect strategies that consist of metacognitive, affective, and social strategies.

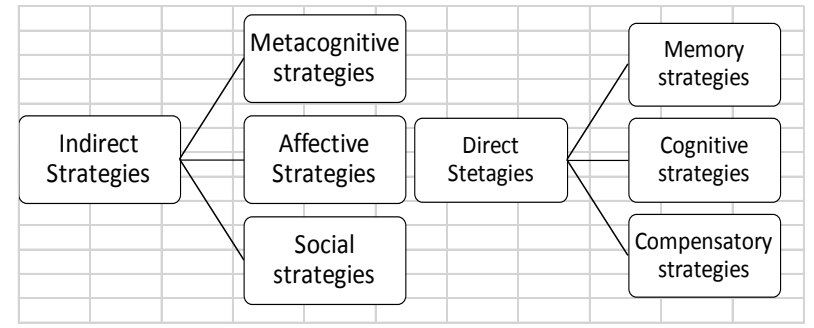

Figure 1. Oxford's (1990) Strategy Inventory for Language Learning (SILL)

The first category is called direct strategies because they directly affect the language learning. Memory strategies, displayed in Figure 1, help language learners store information in their minds so that they can retrieve them when they need them for communication. This includes many different functions. First, creating mental linkages help learners making groups, connecting, and applying different words into different contexts. Cognitive strategies' main function is practicing that helps learners to build self-confidence, increases understanding and enhances fluency. Compensation strategies are important for both level beginning and intermediate learners, because they help them understand and eliminate language limitations in listening, speaking, reading, and writing. They are even useful for advanced learners.

In the second category, indirect strategies offer language learning a different support and are not directly involved the target language learning. Metacognitive strategies, displayed in Figure 1, have many different functions. First, centering learners' learning helps learners to find a focus or center of the basic principles. Second, arranging and planning learners' learning helps learners create a good environment and identify purposes for different tasks. Affective strategies may play an important role in influencing language learners' learning success or failure[12], [13]. It helps in lowering learners' anxiety, helps learners to use progressive relaxation, music, and laughter. Social strategies are related to language learners' behavior regarding their communication with people. They include many different functions. First, asking for information helps learners make clarification and verification. Second, cooperating with others helps learners develop teamwork[11].

\subsection{Studies Conducted on Language Learning Strategies}

Several studies have concluded that the learners who adopt different styles of learning strategies are more successful learners as compared to others [13]-[16] . Similarly many studies also suggest that the more variety of learning strategies a learner uses, the more are his chances of effective learning [13], [17], [18]. As per example Rubin (1981) highlights that language skills will be more strong if a learner tries to speak with natives and watches movies or programs in English [17]. This idea is further enhanced by Oxford who states that learners should have the knowledge about learning strategies, how they complement each other and which of them can enhance, strengthen or have positive effects on each other to achieve desired learning goals. Otherwise selecting inappropriate learning strategies may not prove to be sufficiently effective in language learning [19].

A study implemented by Green and Oxford (1995) to find relationship between language learning strategies and proficiency concludes that the learners with higher level of proficiency in language uses several strategies for learning 
[13]. The research further states that this relationship between learning strategies and proficiency is "ascending spirals" meaning the students who benefited in form of language proficiency by using multiple strategies have greater chance of success by using the same active strategies in future learning.

However, other research studies also revealed that, similar to the successful language learner, unsuccessful learners also understand using different leaning strategies, but in a different way ( [20], [20], [21] . These unsuccessful learners seem to be unaware of how to choose the most appropriate strategies and how to make use of the effective strategies [20]-[22].

\subsection{Gen $\mathrm{Z}$ as Digital Natives}

The classical meaning of term generation is the action that produces offspring. However, Scott and Marchall explains the word generation as products of age sets, identifying that people who were born in specific defined set of time. [23]. Nevertheless, in the end of $20^{\text {th }}$ century the word generation became more associated with social attributes and became distant from biological or medical characteristics. As a result, Generation X, Y and Z were grouped heaving social, political and technological influence. Since Gen $\mathrm{Z}$ is technologically the most advanced, they are best suitable for the title Digital native. Table 2 illustrates a brief overview about the regimentation of Generation Z [24].

Some factors including ontological and sociological and historical separates Gen Z form other generation. First factor is age related, second technological related and third is about events. This generation is in the process of attaining higher education and their parents if not born with technology, are still one of the generation who are delightfully connected and acquainted with technology. This generation is known for its ability of multi-tasting probably given by the easy access of internet. Their target is not achieving accuracy, but they are more focused on speech and are therefore, found moving rapidly from one chore to another. Unlike the previous generations they don't have to struggle hard or read books for a piece of information. With the help of world wide web, they can have any information just with a click. (Mission and Ministry 2010). Since Generation Z life is based on digital technology for communication and as social interaction it will not be wrong to call them Digital Natives.

The people born after 1980 are identified as Digital Natives (including Generation Z) as they are brought up in an environment closely familiar with technology, who are good at using technology as compared to their previous generations [25], [26].

Based on the fact that this generation is techno friendly, different educators have given them different names, Tapscott calls them "Net generation" [27] Whereas Oblinger, Oblinger, and Lippincott calls them "Millennials." [28], While Rose likes to refer them as "i-Generation"[29]. The mentioned terms associated with this generation are solely based on the fact that these people are use new technology more than any previous generation [30]. Although they have been referred to with different names they carry the same feature of digital natives which distinguishes them from other generations.[31].

Prensky coined the term "Digital native". In his book Prensky [8] (2001), labels those as digital natives who use mobile phones, computers and video games. Although like all generations digital natives are also classified by age because not everyone from the same group has access to technology and cannot be called digital natives. But some argue that age is not the only deciding factor. Digital natives have some common experiences and characteristics associated with using information technology and communication with other people and organizations. Prensky focuses on only the digital natives who use technology as an essential part of their life and are good at multitasking, are dependent on visual or pictorial communication and are used to prompt responses and rewards [8]. This generation's brain functions in a unique and different way from their previous generations as a result of being brought up with technology in hand.

Table 1. Categories of Gen $\mathrm{Z}$ regimentation

\begin{tabular}{|c|c|c|c|c|}
\hline Gen & Born & Social environment & Technological environment & Historical environment \\
\hline $\mathbf{X}$ & 1960 and 1974 & $\begin{array}{c}\text { Highly family orientated and } \\
\text { adoption of career very late } \\
\text { in life as compared next } \\
\text { generations }\end{array}$ & $\begin{array}{c}\text { The introduction of home Pc, } \\
\text { internet and video games }\end{array}$ & $\begin{array}{c}\text { Experienced cultural and political } \\
\text { revolutions including collapse of } \\
\text { USSR and demolition of Berlin } \\
\text { Wall. }\end{array}$ \\
\hline $\mathbf{Y}$ & Between 1975-1989 & $\begin{array}{c}\text { Going through political and } \\
\text { social development }\end{array}$ & $\begin{array}{c}\text { Familiarity with the time of } \\
\text { communication Technology }\end{array}$ & $\begin{array}{c}\text { Against 1960s prow culture } \\
\text { attitude, getting use to technology } \\
\text { in daily life }\end{array}$ \\
\hline $\mathbf{Z}$ & $\begin{array}{c}\text { From the } \\
\text { mid-1990s to } \\
\text { the late 2000s }\end{array}$ & $\begin{array}{c}\text { Instant-online, holding } \\
\text { nicknames }\end{array}$ & $\begin{array}{c}\text { Fully-technology } \\
\text { communicators }\end{array}$ & $\begin{array}{c}\text { Social networking - } \\
\text { world perceived } \\
\text { without time and space limits }\end{array}$ \\
\hline
\end{tabular}

NOTE: From "Generations x, y, z: How social networks form the concept of the world without borders (the case of Lithuania)" by Levickaite, R. (2010) 
Literature points out that Teaching/Learning of English language was one of the primary fields that accepted the interference of and collaboration with technology in the start of 80's [32], [33]. However still, there is lack of studies related to performance of technology in language learning. Although in the last few decades' variety of technology such as computer, audio and video devices have proven to be helpful in language learning in higher education. According to Thorne technology has played a special part in the creation of authentic learning environment [34]. The thorough study of some researches about higher education would make us reach a conclusion that technology in the $21^{\text {st }}$ century is inseparable part of langue curricula [35], [36].

\section{Digital Technology in Pakistan}

Pakistan is on its way to transform from non-digital to a digital regime. This transformation started in around 2000[37]. Computers were introduced in Pakistan in certain industries that include state bank, PIA and WAPDA around 35 years back. There was a time when ban was imposed upon the import of computers during 1970's and 1980 's. To import a computer a license was required from the government. It has been almost 35 years since the computers first came to Pakistan when certain banks, PIA and WAPDA installed computers at their head offices. This ban was removed in mid-1980's. IT and telecom sections were set up by the government in in March 2000 [38]. Pakistan announced its first IT policy in the same year. Since then there has been a gradual progress in the use of digital technology in the country. Although adopted from Economist Intelligence Unit e-readiness rankings 2007. It shows that out of 69 countries, Pakistan lies in the 67th position; its score increased from 3.03 in 2006 to 3.79 in 2007 [39]. According to IWS report in 201722.2 percent of the total population of Pakistan uses internet. Detail digits given by IWS are presented in table 2 [40]. There has been great increase in the usage of internet in the country since then.

Internet Usage and Population Statistics:

\begin{tabular}{|l|l|l|l|l|}
\hline 2000 & 133,900 & $163,985,373$ & $0.1 \%$ & US\$ 490 \\
\hline 2006 & $12,000,000$ & $167,806,831$ & $7.2 \%$ & US\$ 821 \\
\hline 2009 & $18,500,000$ & $174,578,558$ & $10.6 \%$ & US\$ 1,017 \\
\hline 2010 & $18,500,000$ & $177,276,594$ & $10.4 \%$ & US\$ 1,068 \\
\hline 2016 & $34,342,400$ & $192,758,348$ & $17.8 \%$ & US\$ 1,500 \\
\hline 2018 & $44,608,065$ & $200,813,818$ & $22.2 \%$ & N/A \\
\hline
\end{tabular}

Note: International Monetary Fund, Retrieved form https://www.internetworldstats.com/asia/pk.htm

Indeed, computers brought digital transformation in the country to a big instant but the contribution of mobile phones cannot be ignored as well. The invention of mobile phone brought speed in the expansion of digital technology. Fixed phone was invented in the $19^{\text {th }}$ century and the first mobile phone was invented by Swedish Mobile in the mid- $20^{\text {th }}$ century. The company named it as a portable mobile phone. It was introduced by Motorola in 1983 [41]. After its invention its usage spread in no time. Within few years of its invention it was being used by 3.3 billion users [42].

Pakistan was not lagging behind in the use of this technology as well. Approximately 90 percent of Pakistanis live within areas that have cell phone connectivity. While large number of Pakistanis possess cell phones. This facts make Pakistan the highest mobile penetration country in the South Asian region [43]. Mobile users increased from 300,000 in 2001 to $90,00,000$ in 2008 (www.techlahore.com). According to a survey conducted by Pakistan Telecommunication Authority in 2010, 98 million Pakistanis use mobile phones. The growth rate increased from 55 percent in April 2010 to 72 percent in May 2010. Total mobile phone users were estimated to be 98 million in May, 2010 [37]. This rate makes it one of the fastest growing businesses in Pakistan.

Gallup Pakistan and Gilani Research Foundation conducted a research in Pakistan in 2017. According to this study 38 percent of the population spend approximately two hours every day using mobile phones. Then came the smart phones. The users of smart phones increased five times from 2014 to 2020. Pakistan was ranked somewhere in the middle field of Asian Pacific countries in the usage of mobile phones. Out of every hundred persons seventy-three were having mobile phones [42]. This access to technology makes generation $\mathrm{Z}$ in Pakistan truly digital natives.

\section{Theoretical Framework}

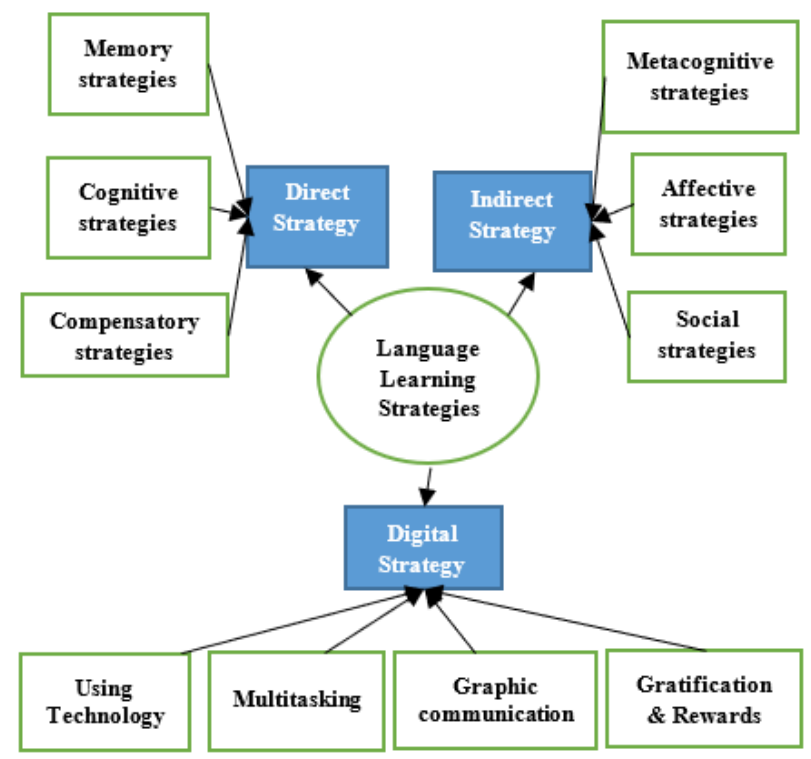

Figure 2. Learning strategies for theoretical framework adopted form oxford (1990) and Teo (2013)

The figure represents three different categories of 
learning strategies. The first two, direct and indirect strategies were presented by Oxfored in 1990 and the third one is the latest identified by Perskey in 2001. Teo's DANS was used to measure its subcategories. Digital strategy includes four subcategories that is; using technology, multitasking, graphic communication and gratification \& reward which are more in line with the learning strategies of Gen Z. Direct and Indirect are the classic learning strategies measured by LLS used by different researches in different countries. Direct strategy consists of three subcategories including memory, cognition and compensation. Indirect strategy is also made up of three subcategories including metacognition, Affective and social strategy. The traditional formwork only considers direct and indirect strategy, however, the contribution of this study will be finding out the usability of digital strategies in addition to the earlier mentioned strategies.

\subsection{Objectives of the Study}

The current study aims to find three main objectives i.e. to find out the different language learning strategies used by Gen Z ESL learners in Pakistan, to explore the different digital learning strategies exploited by Gen Z ESL learners in Pakistan and to identify the most and the least frequently used learning strategies used by Gen Z ESL learners in Pakistan.

\section{Research Methodology}

As the study needed to investigate the believes and attitudes of learners representing different language learning strategies, phenomenological survey method was adopted to investigate the objectives of the study. The Oxford language learning strategies inventory and Digital language learning strategies questionnaire were selected as instruments for data collection form Gen $\mathrm{Z}$ of Pakistan. Data were collected from 120 MA English previous year students selected through simple random sampling techniques from National University of Modern language. It was analyzed through frequency and Chi-square in SPSS.

\subsection{Population and Sample of the Study}

Population for the undertaken study included all the Gen $\mathrm{Z}$ students studying English at graduate level (MA first year) in Pakistan. Analysis of the study could be generalized on the students having the same traits and qualities. As far as sample of the study in concert different researchers use different types of sampling methods depending on the nature of study and feasibility of population. The researcher selected simple random sampling techniques 120 ESL learners from the NUML University studying English as a compulsory subject in first year.

\subsection{Instrument for the study}

\subsubsection{Strategy Inventory for Language Learning}

The tool selected for this study was Strategy Inventory for Language Learning (SILL) presented by Oxford in 1990 [11]. In order to know about learners' language learning strategies for adults self-reported scale is the best choice. The scale consists of 50 items divided into 6 categories that is:(a) memory strategies ( 9 items); (b) cognitive strategies (14 items); (c) compensation strategies (6 items); (d) metacognitive strategies (9 items); (e) affective strategies (6 items); and (f) social strategies (6 items). The response to all the questions are based on five-point Likert scale ranging from 1 representing never true of me, to 5 representing always true of me. According to several previous studies using this instrument, it has Cronbach alpha of 0.67 to 0.95 making it a highly reliable instrument[44], [45].

\section{Digital Natives Assessment Scale (DNAS)}

The current study has adapted DNAS scale developed by Teo in 2013 (for measuring the characteristics of digital natives) to make it more in line with language learning [46]. The adaption process is strictly followed to make the instrument statistically valid and reliable [46], [47]. The scale is constructed on the basis of Prensky "Digital Native" and includes all the attributes predefined by him about digital natives [8]. The instrument consists of for features: raised with technology having five items; comfortably doing multi-tasking having six items; graphics for communication having five items and thrive on instant gratification and rewards consisting of five items. Each item was measured using a seven-point Likert scale, from 1(strongly disagree) to 7 (strongly agree).

Despite the strong psychometric reliability and overall face validity of DNAS, we identified that the instrument did not fulfill the requirement of the current study in its present form. The instrument was modified with the help of three experts in the field of English language and linguistics, and Education. The adapted form of the items along with the original forms is presented in table 1 . In Subsection I "Grow up with technology" all Five items were modified with the addition of "English" to make it more relevant to the current study as the previous version was only about digital natives ignoring its link with English language. The same was done with section II "Comfortable with Multitasking". It was made sure that all the tasks mentioned in the items should be relevant to at least one of the skills of English language. Sub scale III "Reliance on graphics for communication" had total four items of which three items were modified by the experts but in subsection IV "use to immediate gratifications and rewards" only one item was modified for the purpose of clarity. The rest of 3 items were used as they were. 


\section{Data Analysis}

Table 2. Details and Rationale for Adaptations Made in the Items

\begin{tabular}{|c|c|c|c|}
\hline $\begin{array}{l}\text { Item } \\
\text { No }\end{array}$ & Original Item & Adapted Item & Rationale \\
\hline \multicolumn{4}{|c|}{ Grow up with technology } \\
\hline 1 & I use the internet every day. & $\begin{array}{l}\text { I practice English by using internet } \\
\text { every day. }\end{array}$ & $\begin{array}{l}\text { Since the purpose of the tool is to measure } \\
\text { language learning strategies "Practice English" } \\
\text { is added to the question. }\end{array}$ \\
\hline 2 & $\begin{array}{l}\text { I use computers for many things in } \\
\text { my daily life }\end{array}$ & $\begin{array}{l}\text { I use computer for practicing different } \\
\text { English skills in my daily life. }\end{array}$ & $\begin{array}{l}\text { Again "many things" is replaced with } \\
\text { "practicing English skills" to make the tool } \\
\text { more in line with its use. }\end{array}$ \\
\hline 3 & $\begin{array}{l}\text { When I need to know something, I } \\
\text { search the internet first }\end{array}$ & $\begin{array}{c}\text { When I need to know something, } 1 \\
\text { search the internet first using English } \\
\text { language. }\end{array}$ & $\begin{array}{l}\text { An extension of using English language is } \\
\text { added to make it relevant. }\end{array}$ \\
\hline 4 & $\begin{array}{l}\text { I use the computer for leisure } \\
\text { every day. }\end{array}$ & Deleted & $\begin{array}{l}\text { Item Four was deleted as the tool is about } \\
\text { learning strategies not about leisure activities. }\end{array}$ \\
\hline 5 & $\begin{array}{l}\text { I keep in contact with my friends } \\
\text { through the computer every day }\end{array}$ & $\begin{array}{l}\text { I keep in contact with my friends } \\
\text { through the internet every day }\end{array}$ & $\begin{array}{l}\text { The word "computer" was replaced by } \\
\text { "internet" which encompasses many digital } \\
\text { gadgets including computer }\end{array}$ \\
\hline & \multicolumn{3}{|c|}{ Comfortable with Multitasking } \\
\hline 1 & $\begin{array}{l}\text { I am able to surf the internet and } \\
\text { perform another activity } \\
\text { comfortably }\end{array}$ & $\begin{array}{l}\text { I am able to surf the internet and } \\
\text { perform another activity comfortably } \\
\text { using English language. }\end{array}$ & $\begin{array}{l}\text { An addition was made at the end of statement of } \\
\text { "using English language" to make it relevant to } \\
\text { the subject. }\end{array}$ \\
\hline 2 & $\begin{array}{l}\text { I can check email and chat online } \\
\text { at the same time. }\end{array}$ & $\begin{array}{l}\text { I can check email and chat online at the } \\
\text { same time in English Language. }\end{array}$ & $\begin{array}{l}\text { An addition was made at the end of statement of } \\
\text { "in English language" to make it relevant to the } \\
\text { subject }\end{array}$ \\
\hline 3 & $\begin{array}{l}\text { When using the internet for my } \\
\text { work, I am able to listen to music } \\
\text { as well. }\end{array}$ & $\begin{array}{l}\text { When using the internet for my study, I } \\
\text { am able to listen to music as well. }\end{array}$ & $\begin{array}{l}\text { The word "work" was replaced by study as the } \\
\text { instrument is to be used by students. }\end{array}$ \\
\hline 4 & $\begin{array}{l}\text { I am able to communicate with my } \\
\text { friends and do my work at the } \\
\text { same time. }\end{array}$ & $\begin{array}{l}\text { I am able to communicate in English } \\
\text { language with my friends and do my } \\
\text { work at the same time. }\end{array}$ & $\begin{array}{l}\text { An extension of "English Language" has been } \\
\text { added to the sentence to make it more relevant. }\end{array}$ \\
\hline 5 & $\begin{array}{l}\text { I am able to use more than one } \\
\text { applications on the computer at } \\
\text { the same time. }\end{array}$ & $\begin{array}{l}\text { I am able to use more than one } \\
\text { applications on the computer at the } \\
\text { same time utilizing my English } \\
\text { language skills. }\end{array}$ & $\begin{array}{l}\text { An addition was made at the end of the } \\
\text { statement i.e. "utilizing my English language } \\
\text { skills" to know the applications used by } \\
\text { students are utilizing their English skills. }\end{array}$ \\
\hline \multirow[t]{2}{*}{6} & $\begin{array}{l}\text { I can chat on phone with a friend } \\
\text { and message another at the same } \\
\text { time. }\end{array}$ & $\begin{array}{l}\text { I can chat on phone with a friend and } \\
\text { message another at the same time in } \\
\text { English language. }\end{array}$ & $\begin{array}{l}\text { An addition was made in the end of statement } \\
\text { "English language" to make it relevant to the } \\
\text { topic. }\end{array}$ \\
\hline & \multicolumn{3}{|c|}{ Reliant on graphics for communication } \\
\hline 2 & $\begin{array}{l}\text { I use a lot of graphics and icons } \\
\text { when I send messages. }\end{array}$ & $\begin{array}{l}\text { I use a lot of graphics and icons when I } \\
\text { send messages in English language. }\end{array}$ & $\begin{array}{l}\text { Addition of "English Language" for making } \\
\text { statement more relevant to the topic }\end{array}$ \\
\hline 3 & $\begin{array}{l}\text { I prefer to receive messages with } \\
\text { graphics and icons. }\end{array}$ & $\begin{array}{l}\text { I prefer to receive messages written in } \\
\text { English with graphics and icons. }\end{array}$ & $\begin{array}{c}\text { Addition of words "written in English } \\
\text { language" was added for bringing relevance to } \\
\text { the topic. }\end{array}$ \\
\hline 4 & $\begin{array}{l}\text { I use pictures to express my } \\
\text { feelings better. }\end{array}$ & $\begin{array}{l}\text { I use pictures to express my feelings } \\
\text { better while communicating with } \\
\text { others. }\end{array}$ & $\begin{array}{l}\text { Addition of words "while communicating with } \\
\text { other" for making the statement clear }\end{array}$ \\
\hline & \multicolumn{3}{|c|}{ Thrive on instant gratifications and rewards. } \\
\hline 5 & $\begin{array}{l}\text { When I study, I prefer to learn } \\
\text { those that I can use quickly first }\end{array}$ & $\begin{array}{l}\text { When I study, I prefer to learn those } \\
\text { words that I can use quickly first }\end{array}$ & $\begin{array}{l}\text { Addition of "words" is made in the statement to } \\
\text { clarify its purpose. }\end{array}$ \\
\hline
\end{tabular}

Table 3 presents the internal consistency scores which is obtained through Cronbach's alpha to administer DNAS [46] after adaption. The alpha score is established for all the four subsections separately and in total. The alpha coefficients for the total score is 0.85 . Law (1987) claims that for an instrument to be acceptable the level of alpha coefficient total score of $>0.70$ proving internal consistency.
Table 3. Internal consistency coefficients for the subscale and total scores of the DNAS

\begin{tabular}{|c|c|}
\hline Subscale & Alpha score \\
\hline Using Technology & 0.83 \\
\hline Multitasking & 0.80 \\
\hline Graphic Communication & 0.68 \\
\hline Gratification \& Rewards & 0.71 \\
\hline Total & 0.85 \\
\hline
\end{tabular}


Table 3 represents the test-retest reliability scores which is derived using Pearson product moment correlations for the four subscales and total score of the DNAS. Test-retest is calculated in order to verify the reliability of the scale. Law further says that if the data is in form of interval or ratio and for test-retest design person product moment correlation can be applied. The result of the test-retest shows the DNAS subscale range from 0.63 to 0.72 whereas its total coefficient score is 0.73 . As per Shoukri and Pause (1999) the obtained score form test-retest proves the instrument to be reliable enough as it falls in between the standard range of $0.40,0.75$.

Test-retest reliability coefficients for subscale and total scores of the Digital Native Assessment Scale (DNAS) ( $n=$ 21)

\begin{tabular}{|c|c|c|}
\hline Subscale & Correlation (r) & Significance (p) \\
\hline Using Technology & 0.72 & $\mathbf{0 . 0 0 1}$ \\
\hline Multitasking & 0.70 & 0.001 \\
\hline Graphic Communication & 0.63 & 0.001 \\
\hline Gratification \& Rewards & 0.65 & 0.001 \\
\hline Total & 0.73 & 0.001 \\
\hline
\end{tabular}

Table 4 represents Direct and Indirect strategies measured through SILL inventory designed by Oxford in 1990 and digital strategy measured through DNAS scale which was introduced by Tea in 2013 . The table clearly shows all the strategies to be significant except for one strategy falling in Indirect strategy category i.e. Affective strategies with significance of 0.0611 which is more than 0.005 thus making it insignificant. Another hardly significant strategy that falls in the Direct strategy category is Memory strategies having significance level of 0.0511 which is almost equal to 0.05 . Four strategies including Cognitive, Compensatory, Metacognitive and Gratification and Rewards strategies have the significance value above 0.04 making them moderately significant as compared to other strategies. The main difference is highlighted by highest significant strategies that mostly falls in Digital strategy category including Using Technology with 0.00 significance followed by Graphic Communication and Multitasking having 0.014 and 0.034 values consecutively. Whereas social strategies in Indirect Category also carries the same level of high significance with value of 0.005 .

Table 4. Significance of difference Strategies for male and female ESL learners

\begin{tabular}{|c|c|c|c|c|}
\hline Categories of Learning Strategies & All $(n=120)$ & Females $(n=46)$ & Males $(n=74)$ & $P$ value \\
\hline \multicolumn{5}{|l|}{ Direct Strategy } \\
\hline Memory strategies & 120 & $38(82.60)$ & $58(74.37)$ & 0.0511 \\
\hline Cognitive strategies & 120 & $32(69.56)$ & $60(81.08)$ & 0.0421 \\
\hline Compensatory strategies & 120 & $32(69.56)$ & $62(83.78)$ & 0.0433 \\
\hline \multicolumn{5}{|l|}{ Indirect Strategy } \\
\hline Metacognitive strategies & 120 & $33(71.73)$ & $60(81.06)$ & 0.0458 \\
\hline Affective strategies & 120 & $34(73.91)$ & $64(86.48)$ & 0.0611 \\
\hline Social strategies & 120 & $32(69.56)$ & $62(83.78)$ & 0.0056 \\
\hline \multicolumn{5}{|l|}{ Digital Strategy } \\
\hline Using Technology & 120 & $44(95.46) *$ & 73 (98.64) & $<0.0001 *$ \\
\hline Multitasking & 120 & $42(91.30)$ & $69(93.24)$ & $0.0348 *$ \\
\hline Graphic Communication & 120 & $42(91.30)$ & $70(94.59)$ & $0.0147 *$ \\
\hline Gratification \& Rewards & 120 & $39(84.78)$ & $72(97.29)$ & 0.4318 \\
\hline
\end{tabular}




\section{Discussion and Conclusions}

The goal of the study was to identify different learning strategies used by Gen Z ESL learners in Pakistan. Many studies have explored language learning strategies in the light of Direct and Indirect learning strategies. Whereas Gen $\mathrm{Z}$ also known by the name of digital natives have not been analyzed in the light of digital technology strategies. The learners of gen $G$ are highly influenced by different forms of technology especially relating to internet and forms social media communication. The current study investigated the importance of digital technology strategies for the Gen Z ESL learners in Pakistan.

Analysis of the data for the current study demonstrates the answer to the first research question that is what different language learning strategies are applied by Gen Z ESL. The data supports the past studies [13] [14], [16], [18] that English language learners utilizes both direct and indirect learning strategies. With the advancement and increasing use of digital technology most of the Gen $\mathrm{Z}$ is focused on sharpening these strategies but the classic strategies (direct and indirect) are equally important and should not be ignored. The fact of matter is that learning strategy do not exist in isolation. Learners have to use different strategies hand in hand in order to maximize their utility.

However, if we discuss in detail the study the direct, indirect and the digital learning strategies there will be some differences as compared with the past studies. The findings of the current study supports the previous studies related to direct strategies by e.g., Lan \& Oxford and A. Uhl Chamot and P. B. El-Dinary [22][18] proving that learners benefit form more than one strategy for learning language. Study conducted by Chen (2009) states that students' compensation strategy and grad don't carry any significance [48]whereas the current study shows it to be borderline significant for Gen Z of Pakistan.

However there has been research that show that in indirect strategies, ([49] [44] [50], metacognitive strategies are as liked by the learners in the field in EFL. These studies contradict the current research. This study proves that metacognitive strategies are rarely used by the learners in comparison with other strategies. Nevertheless, some studies (Asma Shahid Kazi and Hafiz Muhammad Iqbal and Hong [49][44], suggest that students prefer the use of social strategies, that support the current research.

Use of digital technology is the focal point of this study. The results of this research is also supported by Weaver \& Nilson [51]. According to this research wireless digital technology has become an integral part of our education. Right from the time of independence the students in Pakistan have been trying to acquire the skill of English language realizing its importance in the global market and communicative value. However, till date learners face many difficulties including anxiety, teacher centered classroom and may more. The use of technology can be one of the solution to these problems. Teachers, parents and society need to encourage the learners to practice improving their digital strategies for learning the language.

Pakistan is a developing country and it is not considered technologically advanced but even then the result of data analysis points out that Gen $\mathrm{Z}$ is more into digital learning strategies [37]. The government needs to understand and take steps in this regard to promote learning through digital learning strategies in language learning as well as other fields.

The digital technology has been proven to be important attribute of Gen $\mathrm{Z}$ as is proven by the current study and supported by [52] [35], [52], [54], [55]. It has been suggested that, whenever possible, objects, draw pictures or act out meanings of what is said when trying to communicate with non-English speaking students [56]. Digital technology is the newest form of audio-visual aid. It has the same effect on human brain and can facilitate learner in the same or much better way as any AV aid. Generation $\mathrm{Z}$ lacks patience and is more into quantity of information rather than quality, they are multitaskers and want quick response/reward. Studies have even shown that the use of computers and internet in the classroom may effect students' performance negatively by distracting their attention [52] [53]. But these traits can easily be managed and polished with digital technology for the betterment of the learner. These traits are even the result of being born or brought up by using the digital technology. The current article does not provide any evidence about if the digital learning strategies can actually benefit language learners or not but it only indicates towards the fact that Gen $\mathrm{Z}$ is more into digital learning strategies while learning English language consciously or subconsciously. As in this era, one needs use English language to utilize digital technology which automatically influences their language leaning. Further study is needed to understand the effect of these strategies on language acquisition.

\section{REFERENCES}

[1] T. K. Akinwamide, "The influence of Process Approach on English as second language Students' performances in essay writing," English Lang. Teach., vol. 5, no. 3, pp. 16-29, 2012.

[2] H. Abdul Halim, F. Mahmood, M. Mohammad Ghani, and S. Rajindra, "Motivational Aspects of Using Computers for Writing among the Malaysian ESL Students," Adv. Soc. Sci. Res. J., vol. 1, no. 2, pp. 70-82, 2014.

[3] T. Rahman, "The Urdu-English Controversy in Pakistan," vol. 1, no. 1997, pp. 177-207, 1997.

[4] B. Jorgensen, "Baby Boomers, Generation X and Generation Y? Policy implications for defence forces in the modern era," Foresight, vol. 5, no. 4, pp. 41-49, 2003. 
[5] K. W. Smola and C. D. Sutton, "Generational differences: Revisiting generational work values for the new millennium," J. Organ. Behav., vol. 23, no. SPEC. ISS., pp. 363-382, 2002 .

[6] R. Stern, "Generation Z, Teachers--how's today's 'creative classroom' working for you?," May 14, 2014 at 3:21, 2019.

[7] N. Du Plessis, "Social media in higher education: The case of Facebook. Vaal University of Technology, North-West University: Vaal Campus.," North-West University: Vaal Campus., 2011.

[8] M. Prensky, "Digital natives, digital immigrants.," On the horizon, vol. 9, p. 2001, 2001.

[9] D. W. J. Egnatoff, "Tapscott, D. (1998). Growing Up Digital. The Rise of the Net Generation.," Educ. Inf. Technol., vol. 4, no. 2, pp. 203-205, 1999.

[10] J. Rubin, "Learner strategies: Theoretical Assumptions, Research History and Typology. Learners Strategies in Language Learning," Cambridge Prentice Hall Int., pp. 15$30,1987$.

[11] R. Oxford, Language learning strategies. New York, 1990.

[12] L. Vandergrift, “TV and ergrift, L. (1997) 'The Comprehension Strategies of Second Language (French) Listeners: A Descriptive Study', Foreign Language Annals, 30(3), pp. 387-409. doi: 10.1111/j.1944-9720.1997.tb0236 2.x.he Comprehension Strategies of Second Language (French)," Foreign Lang. Ann., vol. 30, no. 3, pp. 387-409, 1997.

[13] R. Green, J. M. \& Oxford, "A Closer Look at Learning Strategies, L2 Proficiency, and Gender.," Tesol Q., vol. 28, no. 3, 1995.

[14] J. Bruen, "Strategies for success: Profiling the effective learner of German," Foreign Lang. Ann., vol. 34, no. 3, pp. 216-225, 2001.

[15] L. Bachman et al., "Editor SANDRA McKAY," Choice Rev. Online, vol. 4, no. 2, p. 2010, 1987.

[16] C. Griffiths, Patterns of language learning strategy use. System. 2003.

[17] J. Rubin, "Learner strategies: Theoretical assumptions, research history and typology," Learn. Strateg. Lang. Learn., 1987.

[18] R. Lan and R. L. Oxford, "Language learning strategy profiles of elementary school students in Taiwan,"IRAL - Int. Rev. Appl. Linguist. Lang. Teach., vol. 41, no. 4, pp. 339379, 2003.

[19] R. L. Oxford, "Instructional Implications of Gender Differences in Second/Foreign Language (L2) Learning Styles and Strategies," Appl. Lang. Learn., vol. 4, no. 1-2, pp. 65-94, 1993.

[20] L. Vandergrift, "The Comprehension Strategies of Second Language (French) Listeners: A Descriptive Study," Foreign Lang. Ann., vol. 30, no. 3, pp. 387-409, 1997.

[21] R. J. Abraham, R. G., \& Vann, "Strategies of two language learners: A case study.," Learn. Strateg. Lang. Learn., 85-102., p. 1987, 1987.
[22] A. Uhl Chamot and P. B. El-Dinary, "Children's Learning Strategies in Language Immersion Classrooms," Mod. Lang. J., vol. 83, no. 3, pp. 319-338, 1999.

[23] G. Scott, J.; Marshall, "Oxford Dictionary of Sociology." Oxford University Press, 2005.

[24] R. Levickaite, "Generations x, y, z: How social networks form the concept of the world without borders (the case of Lithuania)," Limes, vol. 3, no. 2, pp. 170-183, 2010.

[25] U. Palfrey, J. G., \& Gasser, Born digital: Understanding the first generation of digital natives. 2011.

[26] G. E. Kennedy, T. S. Judd, A. Churchward, K. Gray, and K. L. Krause, "First year students' experiences with technology: Are they really digital natives?," Australas. J. Educ. Technol., vol. 24, no. 1, pp. 108-122, 2008.

[27] D. Tapscott, The rise of the Net generation: Growing up digital. 1998.

[28] J. K. Oblinger, D., Oblinger, J. L., \& Lippincott, Educating the net generation. Boulder, Colo.: EDUCAUSE. 2005.

[29] L. D. Rosen, Rewired: Understanding the iGeneration and the way they learn. St. Martin's Press, 2010.

[30] S. Gibbons, The academic library and the net gen student: Making the connections. American Library Association, 2007.

[31] W. Ng, "Can we teach digital natives digital literacy?," Comput. Educ., vol. 59, no. 3, pp. 1065-1078, 2012.

[32] P. Delcloque, History of CALL. 2000.

[33] M. Warschauer, "Computer-Mediated Collaborative Learning: Theory and Practice," Mod. Lang. J., vol. 81, no. 4, p. $470,1997$.

[34] S. L. (2005). Thorne, "Internet-mediated intercultural foreign language education: Approaches, pedagogy, and research. CALPER Working Paper Series," The Pennsylvania State University, 2005.

[35] P. Gruba, C. Clark, K. Ng, and M. Wells, "Blending technologies in ESL courses: A reflexive enquiry," ASCILITE 2009 - Australas. Soc. Comput. Learn. Tert. Educ., no. January 2009, pp. 402-409, 2009.

[36] E. B. Başoğlu and Ö. Akdemir, "A comparison of undergraduate students' English vocabulary learning: Using mobile phones and flash cards," Turkish Online J. Educ. Technol., vol. 9, no. 3, pp. 1-7, 2010.

[37] A. ur Rehman, "A digital Pakistan," International The News, 2020. [Online]. Available: https://www.thenews.com.pk/pri $\mathrm{nt} / 581540$-a-digital-pakistan.

[38] I. Khawaja, "IT revolution and the digital divide," Dawn's weekly, p. 2001, 2001.

[39] Economic Intelligence Unit, “The 2007 e-readiness rakings: Raising the bar," 2007.

[40] "Internet World Status: Usage and population Statistics," 2017. [Online]. Available: https://www.internetworldstats.c om/asia/pk.htm.

[41] "History of Cell phones." [Online]. Available: https://www.tech-faq.com/history-of-cell-phones.html\%0D. 
[42] S. O’Dea, “Statista," 2020. [Online]. Available: https://www.statista.com/statistics/262950/global-mobile-su bscriptions-since-1993/.

[43] "Pakistan telicommunication Authority," 2012. [Online]. Available:

https://www.pta.gov.pk/index.php/en?Itemid=599\&catid=1 24\%3Aindustry-report\&id=269\%3Atelecom-indicators\&op tion $=$ com_content $\&$ view $=$ article.

[44] K. Hong-nam and A. G. Leavell, "Language learning strategy use of ESL students in an intensive English learning context," vol. 34, pp. 399-415, 2006.

[45] R. Dreyer, C., \& Oxford, "Learner variables related to ESL proficiency among Afrikaan speakers in South Africa.," Lang. Learn. Strateg. around world Cross-cultural Perspect. 61-74., p. 1996, 1996.

[46] T. Teo, "An initial development and validation of a Digital Natives Assessment Scale (DNAS)," Comput. Educ., vol. 67, pp. 51-57, 2013.

[47] P. Young, S. T \& Gates, "Born digital Are they really digital natives," 2014.

[48] M. L. Chen, "Influence of grade level on perceptual learning style preferences and language learning strategies of Taiwanese English as a foreign language learners," Learn.
Individ. Differ., vol. 19, no. 2, pp. 304-308, 2009.

[49] A. S. Kazi and H. M. Iqbal, "Use of Language Learning Strategies by Students at Higher Secondary Level in Pakistan," Soc. Sci., no. October 2011, pp. 557-574.

[50] W. A. Shmais, "Language Learning Strategy Use In Palestine," Electron. J. English as a Second Lang., 2003.

[51] B. E. Weaver and L. B. Nilson, "Laptops in class: What are they good for? What can you do with them?," New Dir. Teach. Learn., no. 101, pp. 3-13, 2005.

[52] D. Cameron, "The Net Generation Goes to University?.," Online Submiss., pp. 1-11, 2005.

[53] L. D. Rosen, "Rewired: Understanding the iGeneration and the way they learn," Int. J. Educ. Integr., p. 2010, 2010.

[54] P. Delcloque, "History of CALL." .

[55] S. L. Bassendowski and P. Petrucka, "Are 20th-century methods of teaching applicable in the 21st century? Sandra Leigh Bassendowski and Pammla Petrucka," Br. J. Educ. Technol., vol. 44, no. 4, pp. 2012-2014, 2013.

[56] S. P. W. Wu and M. A. Rau, "Effectiveness and efficiency of adding drawing prompts to an interactive educational technology when learning with visual representations," Learn. Instr., vol. 55, pp. 93-104, 2018. 